\title{
A review of research on salivary biomarkers for oral cancer detection
}

\author{
Yi-Shing Lisa Cheng ${ }^{1 *}$, Terry Rees ${ }^{2}$ and John Wright ${ }^{1}$
}

\begin{abstract}
Using saliva for disease diagnostics and health surveillance is a promising approach as collecting saliva is relatively easy and non-invasive. Over the past two decades, using salivary biomarkers specifically for early cancer detection has attracted much research interest, especially for cancers occurring in the oral cavity and oropharynx, for which the five-year survival rate (62\%) is still one of the lowest among all major human cancers. More than $90 \%$ of oral cancers are oral squamous cell carcinoma (OSCC) and the standard method for detection is through a comprehensive clinical examination by oral healthcare professionals. Despite the fact that the oral cavity is easily accessible, most OSCCs are not diagnosed until an advanced stage, which is believed to be the major reason for the low survival rate, and points to the urgent need for clinical diagnostic aids for early detection of OSCC. Thus, much research effort has been dedicated to investigating potential salivary biomarkers for OSCC, and more than 100 such biomarkers have been reported in the literature. However, some important issues and challenges have emerged that require solutions and further research in order to find reliable OSCC salivary biomarkers for clinical use. This review article provides an up-to-date list of potential OSCC salivary biomarkers reported as of the fall of 2013, and discusses those emerging issues. By raising the awareness of these issues on the part of both researchers and clinicians, it is hoped that reliable, specific and sensitive salivary biomarkers may be found soon - and not only biomarkers for early OSCC detection but also for detecting other types of cancers or even for monitoring non-cancerous disease activity.
\end{abstract}

Keywords: Saliva; Biomarker; Oral Cancer; Oral squamous cell carcinoma

\section{Introduction}

Worldwide, cancers of the oral cavity and pharynx are the $6^{\text {th }}$ most common type [1]. Although the incidence of oral and pharyngeal cancers is not considered high in the US (it accounts for approximately $3 \%$ of all malignancies in men and $2 \%$ of those in women) [1]- its five-year survival rate has remained around $62 \%$ - in contrast to the fiveyear survival rates for breast cancer $(89 \%)$ and prostate cancer (99\%) [2]. More than $90 \%$ of the oral cancers are squamous cell carcinomas (OSCC), which arise from the epithelial lining of the oral cavity. Even though the oral cavity is easily accessible for direct visual examination, most OSCCs are not diagnosed until an advanced stage, which is believed to be the major reason for the low survival rate. This underscores the importance of early and accurate detection by clinicians, as well as the need to

\footnotetext{
*Correspondence: ycheng@bcd.tamhsc.edu

'Department of Diagnostic Sciences, Texas A\&M University-Baylor College of Dentistry, 3302 Gaston Ave., Dallas, TX 75246, USA

Full list of author information is available at the end of the article
}

educate the public about oral cancer risk factors and prevention.

In responding to the call for early detection of OSCC, several diagnostic adjuncts have been developed, or currently are in development, including the use of salivary biomarkers [3-5]. Saliva has been found to contain constituents that reflect the diseased or physiological state of the human body, and hence could be utilized for diagnostic purposes [6-8]. The search for reliable salivary biomarkers for early detection of OSCC has developed rapidly, spurred on by the fact that collecting saliva is relatively easy and non-invasive, compared to the drawing of blood. From the late 1990s until the present, more than 40 research studies have been published and more than 100 different salivary constituents have been suggested as potential OSCC salivary biomarkers (see Table 1). Several excellent reviews have been previously published concerning the basis for salivary diagnostics, and the history and evolution of salivary proteomic, transcriptomic, genomic, and metabolomic research for oral cancer detection

\section{实}


Table 1 Potential salivary biomarkers for oral cancer detection, reported as of 2013

\begin{tabular}{|c|c|c|}
\hline Category & Potential OSCC salivary biomarkers & Authors/year \\
\hline Non-organic compound & $\mathrm{Na}, \mathrm{Ca}, \mathrm{F}$, and $\mathrm{Mg}$ & Shpitzer et al./2007 [55] \\
\hline Peptide & Defensin-1 & Mizukawa et al./1998 [28] \\
\hline \multirow[t]{45}{*}{ Proteins } & P53 autoantibody & Warnakulasuriya et al./2000 [19] \\
\hline & a-amylase & Chen et al./2002 [20] \\
\hline & IL-8 & St. John et al./2004 [23] \\
\hline & & Rhodus et al./2005 [24] \\
\hline & & Arellano-Garcia et al./2008 [70] \\
\hline & & $\underline{\text { Brinkmann et al./2011 [43] }}$ \\
\hline & & Elashoff et al./2012 [44] \\
\hline & TNF-a & Rhodus et al./2005 [24] \\
\hline & $\underline{\mathrm{IL}-1}$ & \\
\hline & IL-6 & Rhodus et al./2005 [24] \\
\hline & & Katakura et al./2007 [34] \\
\hline & & Saheb-Jamee et al./2008 [35] \\
\hline & & Sato et al./2010 [36] \\
\hline & & Cheng et al./2013 [38] \\
\hline & Basic fibroblast growth factor & Vucicevic et al./2005 [27] \\
\hline & & Gorugantula et al./2012 [39] \\
\hline & Statherin & Contucci et al//2005 [62] \\
\hline & Cyfra 21.1 & Nagler et al./2006 [25] \\
\hline & Tissue polypeptide antigen (TPA) & \\
\hline & Cancer antigen 125 (CA125) & Nagler et al./2006 [25] \\
\hline & & Balan et al./2012 [57] \\
\hline & Endothelin-1 & Pickering et al./2007 [21] \\
\hline & & Cheng et al./2011 [40] \\
\hline & $\mathbb{I L}-1 \beta$ & Katakura et al./2007 [34] \\
\hline & & Brinkmann et al./2011 [43] \\
\hline & & Elashoff et al./2012 [44] \\
\hline & CD44 & Franzmann et al./2007 [46] \\
\hline & Total salivary protein & Shpitzer et al./2007 [55] \\
\hline & Insulin growth factor 1 (IGF-1) & \\
\hline & MMP-2 & \\
\hline & MMP-9 & Shpitzer et al./2007, $2009[49,55$ \\
\hline & CD59 & Hu et al./2008 [29] \\
\hline & Catalase & \\
\hline & Profilin & \\
\hline & S100A9/MRP14 & \\
\hline & $\mathrm{M} 2 \mathrm{BP}$ & Hu et al./2008 [29] \\
\hline & & Brinkmann et al./2011 [43] \\
\hline & & Elashoff et al./2012 [44] \\
\hline & Carcinoembryonic antigen (CEA) & He et al./2009 [54] \\
\hline & Carcinoma associated antigen CA-50 & \\
\hline & Salivary carbonyls & Shipitzer et al./2009 [49] \\
\hline & Cyclin D1 & \\
\hline & Maspin & \\
\hline & 8-oxoguanine DNA glycosylase (OGG1) & \\
\hline & Phosphorylated-Src & \\
\hline
\end{tabular}


Table 1 Potential salivary biomarkers for oral cancer detection, reported as of 2013 (Continued)

\begin{tabular}{|c|c|c|}
\hline & \multicolumn{2}{|l|}{ Ki-67 } \\
\hline & \multirow[t]{2}{*}{ Lactate dehydrogenase } & Shipitzer et al./2009 [49] \\
\hline & & Shetty et al./2012 [58] \\
\hline & Transferrin & Jou et al./2010 [45] \\
\hline & Zinc finger protein 501 peptide & Jou et al./2011 [60] \\
\hline & Hemopexin & Jessie et al./2013 [59] \\
\hline & Haptoglobin & \\
\hline & Complement C3 & \\
\hline & Transthyretin & \\
\hline & a1-antitrypsin & \\
\hline \multirow[t]{4}{*}{ DNAs } & P53 gene codon 63 & Liao et al./2000 [18] \\
\hline & $\begin{array}{l}\text { Loss of heterozygosity in the combination of } \\
\text { markers D3S1234, D9S156, and D17S799 }\end{array}$ & El-Naggar et al//2001 [51] \\
\hline & $\begin{array}{l}\text { Mitochondrial DNAs (cytochrome c oxidase I } \\
\text { and cytochrome c oxidase II) }\end{array}$ & Jiang et al./2005 [37] \\
\hline & $\begin{array}{l}\text { Hypermethylation of promoters in tumor } \\
\text { suppressor genes: DAPK, DCC, MINT-31, } \\
\text { TIMP-31, TIMP-3, p16, MGMT, CCNA1 }\end{array}$ & Carvalho et al./2011 [61] \\
\hline \multirow[t]{20}{*}{ mRNAs } & IL-8 & Li et al./2004 [22] \\
\hline & & Brinkmann et al/2011 [43] \\
\hline & & Elashoff et al./2012 [44] \\
\hline & $\mathrm{IL}-1 \beta$ & Li et al./2004 [22] \\
\hline & & Elashoff et al./2012 [44] \\
\hline & DUSP1 (dual specificity phosphatase 1) & Li et al./2004 [22] \\
\hline & & Elashoff et al./2012 [44] \\
\hline & & Cheng et al./2013 [41] \\
\hline & H3F3A (H3 histone family 3A) & Li et al./2004 [22] \\
\hline & & Elashoff et al./2012 [44] \\
\hline & OAZ1 (ornithin decarboxylase antizyme 1) & Li et al./2004 [22] \\
\hline & & Elashoff et al./2012 [44] \\
\hline & & Cheng et al./2013 [41] \\
\hline & S100P (S100 calcium binding protein P) & Li et al./2004 [22] \\
\hline & & Brinkmann et al//2011 [43] \\
\hline & & Elashoff et al./2012 [44] \\
\hline & & Cheng et al./2013 [41] \\
\hline & SAT (spermidine/spermine N1-acetyltransferase EST) & Li et al./2004 [22] \\
\hline & & Brinkmann et al/2011 [43] \\
\hline & & Elashoff et al./2012 [44] \\
\hline \multirow[t]{3}{*}{ MicroRNAs } & miR-125a & Park et al./2009 [31] \\
\hline & miR-200a & \\
\hline & miR-31 & Liu et al./2012 [33] \\
\hline Long non-coding RNAs & HOTAIR & Tang et al./2013 [56] \\
\hline \multirow[t]{6}{*}{ Oxidative stress-related molecules } & $\begin{array}{l}\text { Reactive nitrogen species (RNS) such as nitric } \\
\text { oxide (NO), nitrites }\left(\mathrm{NO}_{2}\right) \text { and nitrates }\left(\mathrm{NO}_{3}\right)\end{array}$ & Bahar et al./2007 [26] \\
\hline & Peroxidase & Bahar et al./2007 [26] \\
\hline & Glutathione S-transferase (GST) & Bahar et al./2007 [26] \\
\hline & Superoxide dismutase (SOD) & Agha-Hosseini et al/2012 [52] \\
\hline & 8-hydroxy-2-deoxyguanosine (8-OHdG) & \\
\hline & Glutathione & Almadori et al./2007 [30] \\
\hline
\end{tabular}


Table 1 Potential salivary biomarkers for oral cancer detection, reported as of 2013 (Continued)

\begin{tabular}{|c|c|c|}
\hline & Malondialdehyde (MDA) & Agha-Hosseini et al//2012 [52] \\
\hline Glucocorticoid & Cortisol & Bernabé et al./2012 [53] \\
\hline \multirow[t]{6}{*}{ Metabolomics } & $\begin{array}{l}\text { Cadaverine, alpha-aminobutyric acid, alanine, } \\
\text { C5H14N5, piperidine, taurine piperideine, } \\
\text { pipercolic acid, C4H9N, C8H9N, pyrroline } \\
\text { hydroxycarboxylic acid, betaine, C6H6N2O2, } \\
\text { leucine+isoleucine, tyrosine, histidine, } \\
\text { tryptophan, beta-alanine, glutamic acid, } \\
\text { threonine, serine, glutamine, choline, } \\
\text { carnitine, C4H5N2O11P }\end{array}$ & Sugimoto et al./2010 [47] \\
\hline & \multirow[t]{2}{*}{ Phenylalanine } & Wei et al./2011 [48] \\
\hline & & Sugimoto et al./2010 [47] \\
\hline & \multirow[t]{2}{*}{ Valine } & Wei et al./2011 [48] \\
\hline & & Sugimoto et al./2010 [47] \\
\hline & Lactic acid & Wei et al./2011 [48] \\
\hline \multirow{2}{*}{$\begin{array}{l}\text { Glycosylation- } \\
\text { related molecules }\end{array}$} & Sialic acid & \multirow[t]{2}{*}{ Vajaria et al./2013 [32] } \\
\hline & a-L-fucosidase & \\
\hline Other & Telomerase activity & Zhong et al./2005 [50] \\
\hline
\end{tabular}

[6,7,9-14]. This review article will provide an up-to-date list of potential OSCC salivary biomarkers, as of the fall of 2013, and will focus on some emerging issues/challenges that seem to be major roadblocks on the way to bringing reliable salivary biomarkers into actual clinical use. The intention of this review is to increase awareness of these issues on the part of both researchers and clinicians, with the hope that good solutions may be generated more quickly by group efforts in this field. Addressing these issues not only will serve to accelerate progress toward finding reliable salivary biomarkers for early OSCC detection, but also should have a positive effect on the search of reliable salivary biomarkers for other types of cancer detection or even for monitoring non-cancerous disease activity.

\section{Review}

Whole saliva (oral fluid) is unique and complex, both in its sources and composition. It consists not only of secretions from the three major salivary glands (parotid, submandibular and sublingual) and the minor glands, but also gingival crevicular fluid, oral mucosa transudate, secretions from nasal and pharyngeal mucosa, nonadherent bacteria, desquamated oral epithelial cells, keratin debris, blood cells, and perhaps food or medication residuals [8]. The functions of saliva include lubrication, digestion, antimicrobial activity, facilitating remineralization of the tooth enamel, and maintaining normal taste sensation [15]. These important functions are achieved by the various chemical components of saliva including water, inorganic compounds (ions), organic compounds (non-proteins and lipids), protein/polypeptides, and hormones [15]. Salivary proteins and polypeptides constitute a significant portion of the mix, and play an important role in carrying on the main functions of saliva. So far, more than 2300 proteins and peptides have been found in human saliva [16]. The most abundant proteins are $\alpha$-amylase, albumin, cystatins, hystatins, secretory-IgA, lactoferrin, mucins, lysozymes, proline rich proteins, statherin and transferrin-which together account for more than $98 \%$ of the total salivary proteins $[15,17]$. Most of the potential OSCC salivary biomarkers are also salivary proteins (see Table 1). However, except for three, $\alpha$-amylase, statherin, and transferrin, those proteins, as well as the non-protein OSCC salivary biomarker candidates, are present in a very low concentration in saliva and require methods/instruments with high sensitivity for detection.

\section{Reported potential salivary biomarkers for oral cancer detection}

So far, more than 100 potential OSCC salivary biomarkers have been reported in the literature, based mainly on comparing the levels found in OSCC patients to the levels found in non-OSCC normal controls (see Table 1) [18-62]. Some of these potential OSCC salivary biomarkers have been investigated by more than one research group; however, in some studies, no significant differences have been found in IL-6 [23], IL-8 [34,35] and endothelin-1 [63] levels between the OSCC patients and their respective control groups.

The research methodology involved so far in investigating these potential OSCC salivary biomarkers can be grouped according to the types of biomarker, as follows:

\section{Non-organic compound biomarkers}

Flame photometry, atomic absorption, and spectrophotometry [55] 


\section{Peptide or protein biomarkers}

High performance liquid chromatography (HPLC)

$[28,62]$

Enzyme-linked immunosorbent assay (ELISA)

$[19,21,23,24,27,34-36,39,40,46,49,54,55,57]$

Radio-immunoassay [25]

Two-dimensional gel electrophoresis (2DE), followed by mass spectrometry (MS) [59]

2DE and reverse-phase liquid chromatography (LC), followed by LC-tandem MS [29]

Matrix-assisted laser desorption/ionization time-of-

flight mass spectrometry (MALDI-TOF MS) [20,60]

2DE followed by MALDI-TOF MS [45]

3. DNA, mRNA or microRNA biomarkers

Polymerase chain reaction (PCR) $[18,37,51]$

Quantitative PCR (qPCR) [31,33,41-44,56]

Microarrays followed by qPCR [22]

4. Metabolomic biomarkers

Capillary electrophoresis TOF MS [47]

HPLC with quadrupole/TOF MS [48]

5. Miscellaneous biomarkers (chemical and enzyme activity)

HPLC [30]

Colorimetric (mostly commercially available) assays

$[26,32,49,50,52,53,58]$

Most OSCC salivary biomarker research has involved investigating the constituents of the whole saliva in an unstimulated state, although two studies did investigate the stimulated saliva samples $[28,36]$. After a saliva sample is collected, a centrifugation processing procedure is often performed to remove the solid constituents (desquamated oral epithelial cells, keratin debris, blood cells, bacteria and food residuals, if any), but some studies appear to have analyzed the whole saliva content without centrifugation [46,54,58,63,64]. After separating out those solid constituents, samples were often stored in a frozen state until further analysis. Most salivary biomarker research studies have investigated only the supernatant (cell-free) portion of the saliva samples, while other studies investigated only the pellet portion of the saliva $[50,51,61]$ or both the supernatant and the pellet portions [49] after centrifugation.

\section{Issues/challenges in OSCC salivary biomarker research 1. A lack of standardization of conditions and methods of saliva sample collection, processing, and storage}

Despite the fact that more than 100 potential OSCC salivary biomarkers have been reported, there has been no standardization regarding the condition of the subjects from whom the saliva samples are collected (e.g., the timing in regard to prior food and drink intake, or the use of oral hygiene products). Similarly, a uniform method has not been established for how the saliva samples are collected, processed and stored prior to measurement and comparison of the biomarker levels in the groups studied.

For example, in regard to participant requirements at the time of saliva collection, all researchers collected saliva samples in the morning, yet some researchers collected saliva samples from participants at least one hour after food intake $[23,25,26,63]$; some collected saliva at least 1 $1 / 2$ hours after food intake [24]; and in ours and another study, we collected saliva in the morning before the participants ate, drank or performed any oral hygiene procedures [30,39-41]. In regard to saliva processing methods, most investigators centrifuged the saliva samples immediately after collection. However, they carried out this procedure with various degrees of centrifugal force and for various lengths of time, such as $800 \mathrm{~g}$ for 10 minutes [25,26,49]; $2000 \mathrm{~g}$ for 10 minutes [52]; $2600 \mathrm{~g}$ for $15 \mathrm{mi}-$ nutes [23,32,40,41,43]; $14,000 \mathrm{~g}$ for 20 minutes [59]; $2000 \mathrm{rpm}$ (gravity not specified) for 5 minutes [53]; $3500 \mathrm{rpm}$ (gravity not specified) for 15 minutes [34]; 14,000 rpm (gravity not specified) for 20 minutes [21]. Others stored the whole saliva samples at $-80^{\circ} \mathrm{C}$ immediately after collection, then later thawed and centrifuged the samples at $4500 \mathrm{~g}$ for 20 minutes [35] or $6000 \mathrm{rpm}$ (gravity not specified) for 20 minutes [24]. In regard to saliva sample preservation, we and some other investigators added proteinase inhibitors or RNase inhibitors to preserve salivary proteins and RNAs, respectively [22,29,39-41], but most investigators did not add any inhibitors. In regard to saliva sample storage, most researchers stored the saliva samples in $-80^{\circ} \mathrm{C}$, although others stored samples at $-20^{\circ} \mathrm{C}$ $[28,52,54]$ or $4^{\circ} \mathrm{C}[30]$.

The differences in these factors among the different studies raises the question as to whether the levels of the potential OSCC salivary biomarkers reported in any one lab could be compared to the levels of the same biomarker reported in any other lab. In fact, for the reported potential biomarkers which have been investigated by more than one study, a wide variability was found in the levels of both the diseased and the control groups among different labs, and the different methods used for collecting and handling the saliva samples are likely to be one of the reasons for that variability. As research efforts will continue to be devoted to this promising field, standardization of saliva collection, processing and storage methods is essential, so that all the research findings among different research groups can be compared and validated, and progress accelerated toward finding the most reliable validated OSCC salivary biomarkers. Without such standardization and validation of biomarkers, valuable research resources are being squandered, because reported results cannot be translated into the desired clinical use and patient outcomes. A panel of experts in this research field is needed to discuss this issue and find a way to establish the standards needed. 


\section{Variability in the levels of potential OSCC salivary biomarkers in both non-cancerous individuals and OSCC patients, suggest unknown confounding factors}

The wide variations noted in the reported levels of some of the salivary biomarker candidates among different research labs obviously creates difficulties in determining the reference level and the OSCC level for any given potential OSCC salivary biomarker. For example, salivary IL6 and IL- 8 are two of the most studied biomarkers, not only for potential OSCC detection but also for monitoring disease activity of chronic periodontitis and oral lichen planus (OLP)-a chronic mucocutaneous inflammatory disease that affects about $2 \%$ of the world population $[65,66]$. As can be seen in Table 2 [23,24,34,35,38,67-72], wide variations in the reported salivary IL-6 and IL-8 levels among the different studies were noted even in the healthy controls, with the average IL-6 levels ranging from $1.4 \pm 0.9 \mathrm{pg} / \mathrm{ml}[24]$ to $47.46 \pm 18.74 \mathrm{pg} / \mathrm{ml}$ [67], and IL-8 levels ranging from $250 \mathrm{pg} / \mathrm{ml}[23,34,35]$ to $1945 \pm$ $181 \mathrm{pg} / \mathrm{ml}$ [68]. When the reference levels vary so much among the different studies, it is impossible to determine what ranges of salivary IL-6 or IL-8 levels are likely to indicate OSCC development. For example, the average salivary IL-8 levels found in OSCC patients in two studies were $720 \mathrm{pg} / \mathrm{ml}$ [23] and $1093.7 \pm 1089.0 \mathrm{pg} / \mathrm{ml}$ [35], respectively -in contrast to $250 \mathrm{pg} / \mathrm{ml}$ and $700.7 \pm$ $1031.5 \mathrm{pg} / \mathrm{ml}$, respectively, in healthy controls. The average salivary IL-8 levels found in chronic periodontitis and healthy controls reported by Teles et al.[68] were $2268 \pm$ 111 and $1945 \pm 181 \mathrm{pg} / \mathrm{ml}$, respectively, both of which would most likely be considered in the concentration range for OSCC by the two previous studies reported by St John et al. [23] and SahebJamee et al. [35].

These wide variations in the levels of the same salivary constituent across the different research studies could be due at least partly to the different processing methods used, as described above. However, they may also possibly be due to inherent biological variations within different individuals and groups. In fact, some studies have reported intra- and inter-subject variability in salivary proteome and in specific potential OSCC salivary protein and mRNA biomarkers in studies of healthy adults [73-75]. Inherent biological variations are known to create difficulties in determining the reference values for biological samples in clinical laboratories [76]. Such variations in salivary constituents could be attributed to differences in ethnic background, geographic locations, age, gender, non-neoplastic systemic diseases, dietary habits, medications being taken or other factors. For example, significantly increased levels in one of the potential salivary OSCC salivary biomarkers, endothein-1, have been reported in patients with chronic heart failure [77] or upper gastrointestinal diseases such as gastric ulcer, duodenal ulcer and gastritis [78] in the absence of OSCC.
Age-related reduction in the concentrations of certain salivary proteins $[79,80]$ has also been reported, although whether there are any significant age-related changes in any of the reported potential OSCC salivary biomarkers has not been determined. In summary, the intra- and inter-subject variability points to an urgent need for more research regarding possibly underlying causes for these inherent biological variations, in order to refine and determine the appropriate reference range for any potential OSCC salivary biomarkers.

\section{The need for further validation of OSCC salivary biomarkers}

Validation in the presence of common oral inflammatory conditions Ideally, a good clinical test requires high sensitivity and specificity. The oral cavity is commonly subject to inflammation from a variety of causes, including trauma, dental plaque, infection and certain mucocutaneous inflammatory diseases. Whether such oral inflammation (non-neoplastic conditions) affects the levels of the potential OSCC salivary biomarkers is essentially unknown, because most studies have investigated the potential salivary biomarker levels only in OSCC patients and non-OSCC controls, without regard for other inflammatory conditions that might have been present [9,21-27]. If the levels of any of the potential OSCC salivary biomarkers are increased in the presence of oral inflammation to a degree that there is no significant difference between those levels and the levels found in OSCC patients, it would result in a high false positive rate and greatly reduce the value of that biomarker in clinical use for OSCC detection.

In review of the reported potential OSCC salivary biomarkers, many of them- such as IL-6 [24,34,35], IL-8 $[23,24,70], I L-1 \beta[22,70]$, basic fibroblast growth factor [27], and molecules related to oxidative stress-[26,30] are known to be important factors involved in inflammation and/or wound healing $[81,82]$. Indeed, the levels of some of these salivary constituents have been reported to be significantly higher or lower in periodontitis or OLP patients who did not have OSCC $[67,69,71,72,83,84]$. Therefore, research that validates any potential OSCC salivary biomarker with individuals having common non-neoplastic oral inflammatory diseases is necessary in order to establish the reliability of that salivary OSCC biomarker.

Validation in the presence of other types of human cancers The advantages (being non-invasive and easy to collect) of using saliva over blood for disease detection and monitoring of disease progression encourage salivary biomarker research activities not only for OSCC detection but also for detection of other types of cancers. For instance, several potential salivary biomarkers for breast and lung cancer detection have been reported in 
Table 2 Salivary Concentrations of IL-6 and IL-8 (pg/ml) in OSCC, OLP, and chronic periodontitis patient groups

\begin{tabular}{|c|c|c|c|c|c|c|c|c|}
\hline \multirow[t]{2}{*}{ Author/reographical region/year } & \multicolumn{2}{|c|}{ OSCC } & \multicolumn{2}{|c|}{ OLP } & \multicolumn{2}{|c|}{ Chronic periodontitis } & \multicolumn{2}{|c|}{ Controls } \\
\hline & IL-6 & IL-8 & IL-6 & IL-8 & IL-6 & IL-8 & IL-6 & IL-8 \\
\hline St. John et al./California, USA/2004 [23] & & 720 & & & & & & 250 \\
\hline Rhodus et al./Minnesota, USA/2005 [24] & $88.2 \pm 43.2$ & $3154.1 \pm 1023.2$ & & & & & $1.4 \pm 0.9$ & $1580 \pm 789$ \\
\hline Rhodus et al./Minnesota, USA/2005 [67] & & & $371.35 \pm 205.52$ & $2194.3 \pm 496.7$ & & & $47.46 \pm 18.74$ & $703.8 \pm 131.6$ \\
\hline Katakura et al./Tokyo, Japan/2007 [34] & 86.5 & 720 & & & & & 0 & 250 \\
\hline Zhang et al./Sichuan, China/2008 [69] & & & $48.79 \pm 8.53$ & $1737.49 \pm 1073.54$ & & & $29.9 \pm 4.68$ & $641.46 \pm 172.91$ \\
\hline Saheb Jamee et al./Tehran, Iran/2008 [35] & $40.9 \pm 79.5$ & $1093.7 \pm 1089.0$ & & & & & $2.5 \pm 1.3$ & $700.7 \pm 1031.5$ \\
\hline Arellano- Garcia et al./California, USA/2008 [70] & & $3347.7 \pm 2929$ & & & & & & $759.4 \pm 563$ \\
\hline Teles et al./Massachusetts, USA/2009 [68] & & & & & & $2268 \pm 111$ & & $1945 \pm 181$ \\
\hline Sharma et al./Manipal, India/2011 [71] & & & & & $311.35 \pm 11.51$ & & $17.15 \pm 8.44$ & \\
\hline Ebersole et al./Kentucky, USA/2013 [72] & & & & & $35.57 \pm 48.17$ & & $3.30 \pm 2.32$ & \\
\hline Cheng et al./Texas, USA/2014 [38] & $178.41 \pm 172.32$ & $1525.33 \pm 1123.95$ & $20.74 \pm 22.28$ & $1328.37 \pm 731.80$ & $5.85 \pm 4.02$ & $738.79 \pm 394.00$ & $4.92 \pm 8.77$ & $890.83 \pm 563.22$ \\
\hline
\end{tabular}

Cheng et al./Texas, USA/2014 [38]

All studies investigated unstimulated whole saliva. 
recent years [85-92]. Some of the reported salivary biomarkers for breast carcinomas, such as CA125 [91], haptoglobin, profilin-1 and transferrin [87]; and one reported salivary biomarker for lung cancer, S100 calcium binding protein A9 [86], are the same ones reported as potential OSCC salivary biomarkers [25,29,57,59]. Salivary annexin A1, carbonic anhydrase VI, S100 calcium binding protein, and lipocalin have also been reported as potential biomarkers for both breast and lung cancers $[86,87]$. These findings suggest that the levels of at least some salivary constituents could be significantly changed by the presence of more than one type of cancer, a fact which points to the necessity of validating the specificity of the reported potential OSCC salivary biomarkers with patients who have other types of cancers.

\section{Conclusion}

Salivary biomarkers represent a promising non-invasive approach for oral cancer detection, and an area of strong research interest. However, some issues/challenges have arisen that need to be resolved in order to establish this approach as a reliable, highly sensitive and specific method for clinical use. These issues include a lack of standardization for saliva sample collection, processing, and storage; wide variability in the levels of potential OSCC salivary biomarkers in both non-cancerous individuals and OSCC patients; and a need for further validation of OSCC salivary biomarkers with individuals who have either a chronic oral inflammatory disease or other types of cancers, but do not have OSCC. These issues call for convening a panel of researchers in this field to aim for eventual standardization, plus further research, especially concerning biological variance and physiological changes affecting the potential oral cancer salivary biomarkers. The experience gained in OSCC salivary biomarker research also can serve as an important reference in salivary diagnostics, including identifying, validating, and applying salivary biomarkers for other types of cancer detection and for monitoring non-cancerous disease activity.

\section{Abbreviations \\ OSCC: Oral squamous cell carcinoma; OLP: Oral lichen planus; HPLC: High performance liquid chromatography; ELISA: Enzyme-linked immunosorbent assay; RIA: Radioimmunoassay; MALDI-TOF MS: Matrix-assisted laser desorption/ ionization time-of-flight mass spectrometry; 2DE: Two-dimensional gel electrophoresis; qPCR: Quantitative polymerase chain reaction.}

\section{Competing interests}

The authors declare that they have no commercial or other competing interests to disclose.

\section{Authors' contributions}

The author YSLC reviewed and analyzed the published research studies, conceptualized and drafted the manuscript. TR and JW contributed important intellectual content for the manuscript. All three authors have been involved in revising the manuscript. All authors read and approved the final manuscript.

\section{Acknowledgements}

Our research work regarding salivary biomarkers has been supported by the National Institute of Dental and Craniofacial Research (1R21DE018757: 5TL1RR024984; 5UL1RR024982), Texas A\&M Health Science Center (TAMHSC), and Department of Diagnostic Sciences, Texas A\&M University-Baylor College of Dentistry. We want to acknowledge Ms. Lee Jordan and Drs. Huey-Shys Chen, Emet Schneiderman, Jaqueline Plemons, Lance Oxford, David Kang, and John O'Brien, for their contributions to our previous and ongoing research regarding OSCC salivary biomarkers. We also want to thank Drs. David Carlson, Larry Wolinsky and Larry Bellinger for their strong support to our research work at Baylor College of Dentistry. Finally, Yi-Shing Lisa Cheng wishes to thank Dr. David Wong, Associate Dean of Research at UCLA, for his encouragement, invaluable advice and support over the years. His speech at the annual meeting of the American Academy of Oral and Maxillofacial Pathology in 2005 inspired our work in this field.

\section{Author details}

'Department of Diagnostic Sciences, Texas A\&M University-Baylor College of Dentistry, 3302 Gaston Ave., Dallas, TX 75246, USA. ${ }^{2}$ Department of Periodontics, Texas A\&M University-Baylor College of Dentistry, 3302 Gaston Ave., Dallas, TX 75246, USA.

Received: 7 January 2014 Accepted: 13 February 2014

Published: 24 February 2014

\section{References}

1. Chi AC: Squamous cell carcinoma. In Oral and Maxillofacial Pathology. Edited by Neville BW, Damm DD, Allen CM, Bouquot JE. St. Louis: Saunders Elsevier; 2009:409-421.

2. Siegel R, Naishadham D, Jemal A: Cancer statistics, 2013. CA Cancer J Clin 2013, 63(1):11-30.

3. Cheng Y, Wright J: Advances in diagnostic adjuncts for oral squamous cell carcinoma. The Open Pathology Journal 2011, 5:3-7.

4. Kalmar JR: Advances in the detection and diagnosis of oral precancerous and cancerous lesions. Oral Maxillofacial Surg Clin N Am 2006, 18:465-82.

5. Patton LL, Epstein JB, Kerr AR: Adjunctive techniques for oral cancer examination and lesion diagnosis: a systematic review of the literature. J Am Dent Assoc 2008, 139(7):896-905.

6. Wong DT: Salivary diagnostics for oral cancer. J Calif Dent Assoc 2006, 34(4):303-8

7. Wong DT: Salivary diagnostics powered by nanotechnologies, proteomics and genomics. J Am Dent Assoc 2006, 137(3):313-21.

8. Castagnola M, Picciotti PM, Messana I, Fanali C, Fiorita A, Cabras T, Calo L, Pisano E, Passali GC, lavarone F, Paludetti G, Scarano E: Potential applications of human saliva as diagnostic fluid. Acta Otorhinolaryngol Ital 2011, 31(6):347-57.

9. Wu J, Yi C, Chung H, Wang D, Chang W, Lee S, Lin C, Yang Y, Yang W: Potential biomarkers in saliva for oral squamous cell carcinoma. Oral Oncology 2010, 46:226-31.

10. Zimmermann B, Wong DT: Salivary mRNA targets for cancer diagnostics. Oral Oncol 2008, 44:425-429.

11. Nagler RM: Saliva as a tool for oral cancer diagnosis and prognosis. Oral Oncol 2009, 45(12):1006-10.

12. Brinkmann O, Wong DT: Salivary transcriptome biomarkers in oral squamous cell cancer detection. Adv Clin Chem 2011, 55:21-34.

13. Zimmermann BG, Park NJ, Wong DT: Genomic targets in saliva. Ann N Y Acad Sci 2007, 1098:184-91.

14. Zhang $A$, Sun $H$, Wang $X$ : Saliva metabolomics opens door to biomarker discovery, disease diagnosis, and treatment. Appl Biochem Biotechnol 2012, 168(6):1718-27.

15. Chiappin S, Antonelli G, Gatti R, De Palo EF: Saliva specimen: a new laboratory tool for diagnostic and basic investigation. Clin Chim Acta 2007, 383(1-2):30-40.

16. Bandhakavi S, Stone MD, Onsongo G, Van Riper SK, Griffin TJ: A dynamic range compression and three-dimensional peptide fractionation analysis platform expands proteome coverage and the diagnostic potential of whole saliva. J Proteome Res 2009, 8(12):5590-600.

17. Messana I, Inzitari R, Fanali C, Cabras T, Castagnola M: Facts and artifacts in proteomics of body fluids. What proteomics of saliva is telling us? I Sep Sci 2008, 31(11):1948-63. 
18. Liao PH, Chang YC, Huang MF, Tai KW, Chou MY: Mutation of p53 gene codon 63 in saliva as a molecular marker for oral squamous cell carcinomas. Oral Oncol 2000, 36(3):272-6.

19. Warnakulasuriya S, Soussi T, Maher R, Johnson N, Tavassoli M: Expression of p53 in oral squamous cell carcinoma is associated with the presence of IgG and IgA p53 autoantibodies in sera and saliva of the patients. J Pathol 2000, 192(1):52-7.

20. Chen YC, Li TY, Tsai MF: Analysis of the saliva from patients with ora cancer by matrix-assisted laser desorption/ionization time-of-flight mass spectrometry. Rapid Commun Mass Spectrom 2002, 16(5):364-9.

21. Pickering $V$, Jordan RC, Schmidt BL: Elevated salivary endothelin levels in oral cancer patients-a pilot study. Oral Oncol 2007, 43(1):37-41.

22. Li Y, St John MA, Zhou X, Kim Y, Sinha U, Jordan RC, Eisele D, Abemayor E, Elashoff D, Park NH, Wong DT: Salivary transcriptome diagnostics for oral cancer detection. Clin Cancer Res 2004, 10(24):8442-50.

23. St John MA, Li Y, Zhou X, Denny P, Ho CM, Montemagno C, Shi W, Qi F, Wu B, Sinha U, Jordan R, Wolinsky L, Park NH, Liu H, Abemayor E, Wong DT: Interleukin 6 and interleukin 8 as potential biomarkers for oral cavity and oropharyngeal squamous cell carcinoma. Arch Otolaryngol Head Neck Surg 2004, 130(8):929-35.

24. Rhodus NL, Ho V, Miller CS, Myers S, Ondrey F: NF-kappaB dependent cytokine levels in saliva of patients with oral preneoplastic lesions and oral squamous cell carcinoma. Cancer Detect Prev 2005, 29(1):42-5.

25. Nagler R, Bahar G, Shpitzer T, Feinmesser R: Concomitant analysis of salivary tumor markers-a new diagnostic tool for oral cancer. Clin Cancer Res 2006, 12(13):3979-84.

26. Bahar G, Feinmesser R, Shpitzer T, Popovtzer A, Nagler RM: Salivary analysis in oral cancer patients: DNA and protein oxidation, reactive nitrogen species, and antioxidant profile. Cancer 2007, 109(1):54-9.

27. Vucicevic Boras V, Cikes N, Lukac J, Virag M, Cekic-Arambasin A: Salivary and serum interleukin 6 and basic fibroblast growth factor levels in patients with oral squamous cell carcinoma. Minerva Stomato/ 2005, 54(10):569-73.

28. Mizukawa N, Sugiyama K, Fukunaga J, Ueno T, Mishima K, Takagi S, Sugahara T: Defensin-1, a peptide detected in the saliva of oral squamous cell carcinoma patients. Anticancer Res 1998, 18(6B):4645-9.

29. Hu S, Arellano M, Boontheung $P$, Wang J, Zhou H, Jiang J, Elashoff D, Wei R, Loo JA, Wong DT: Salivary proteomics for oral cancer biomarker discovery. Clin Cancer Res 2008, 14(19):6246-52.

30. Almadori G, Bussu F, Galli J, Limongelli A, Persichilli S, Zappacosta B, Minucci A, Paludetti G, Giardina B: Salivary glutathione and uric acid levels in patients with head and neck squamous cell carcinoma. Head Neck 2007, 29(7):648-54.

31. Park NJ, Zhou H, Elashoff D, Henson BS, Kastratovic DA, Abemayor E, Wong DT: Salivary microRNA: discovery, characterization, and clinical utility for oral cancer detection. Clin Cancer Res 2009, 15(17):5473-7.

32. Vajaria BN, Patel KR, Begum R, Shah FD, Patel JB, Shukla SN, Patel PS: Evaluation of serum and salivary total sialic acid and alpha-l-fucosidase in patients with oral precancerous conditions and oral cancer. Oral Surg Oral Med Oral Pathol Oral Radiol 2013, 115(6):764-71.

33. Liu C, Lin S, Yang C, Cheng H, Chang K: Exploiting salivary miR-31 as a clinical biomarker of oral squamous cell carcinoma. Head Neck 2012, 34:219-224.

34. Katakura A, Kamiyama I, Takano N, Shibahara T, Muramatsu T, Ishihara K, Takagi R, Shouno T: Comparison of salivary cytokine levels in oral cancer patients and healthy subjects. Bull Tokyo Dent Coll 2007, 48(4):199-203.

35. SahebJamee M, Eslami M, AtarbashiMoghadam F, Sarafnejad A: Salivary concentration of TNFalpha, IL1 alpha, IL6, and IL8 in oral squamous cell carcinoma. Med Oral Patol Oral Cir Bucal 2008, 13(5):E292-5.

36. Sato J, Goto J, Murata T, Kitamori S, Yamazaki Y, Satob A, Kitagawa Y: Changes in saliva interleukin-6 levels in patients with oral squamous cell carcinoma. Oral Surg Oral Med Oral Pathol Oral Radiol 2010, 110(3):330-336.

37. Jiang WW, Masayesva B, Zahurak M, Carvalho AL, Rosenbaum E, Mambo E, Zhou S, Minhas K, Benoit N, Westra WH, Alberg A, Sidransky D, Koch W, Califano J: Increased mitochondrial DNA content in saliva associated with head and neck cancer. Clin Cancer Res 2005, 11(7):2486-91.

38. Cheng Y, Jordan L, Gorugantula L, Schneiderman E, Chen H, Rees T: Salivary interleukins 6 and 8 in oral cancer patients and in patients with chronic oral inflammatory diseases. $J$ of Periodontology. in press.

39. Gorugantula L, Rees T, Plemons J, Chen H, Cheng Y: Salivary basic fibroblast growth factor in patients with oral squamous cell carcinoma or oral lichen planus. Oral Surg Oral Med Oral Pathol Oral Radiol 2012, 114(2):215-22.
40. Cheng YS, Rees T, Jordan L, Oxford L, O'Brien J, Chen HS, Wong D: Salivary endothelin-1 potential for detecting oral cancer in patients with oral lichen planus or oral cancer in remission. Oral Oncol 2011, 47(12):1122-6.

41. Cheng YS, Jordan L, Rees T, Chen HS, Oxford L, Brinkmann O, Wong D: Levels of potential oral cancer salivary mRNA biomarkers in oral cancer patients in remission and oral lichen planus patients. Clin Oral Investig 2013. Jul 28 [Epub ahead of print] PMID: 23892499.

42. Carvalho AL, Jeronimo C, Kim MM, Henrique R, Zhang Z, Hoque MO, Chang S, Brait M, Nayak CS, Jiang WW, Claybourne Q, Tokumaru Y, Lee J, Goldenberg D, Garrett-Mayer E, Goodman S, Moon CS, Koch W, Westra WH, Sidransky D, Califano JA: Evaluation of promoter hypermethylation detection in body fluids as a screening/diagnosis tool for head and neck squamous cell carcinoma. Clin Cancer Res 2008, 14(1):97-107.

43. Brinkmann O, Kastratovic DA, Dimitrijevic MV, Konstantinovic VS, Jelovac DB, Antic J, Nesic VS, Markovic SZ, Martinovic ZR, Akin D, Spielmann N, Zhou H, Wong DT: Oral squamous cell carcinoma detection by salivary biomarkers in a Serbian population. Oral Oncol 2011, 47(1):51-5.

44. Elashoff D, Zhou H, Reiss J, Wang J, Xiao H, Henson B, Hu S, Arellano M, Sinha U, Le A, Messadi D, Wang M, Nabili V, Lingen M, Morris D, Randolph T, Feng Z, Akin D, Kastratovic DA, Chia D, Abemayor E, Wong DT: Prevalidation of salivary biomarkers for oral cancer detection. Cancer Epidemiol Biomarkers Prev 2012, 21(4):664-72.

45. Jou YJ, Lin CD, Lai CH, Chen CH, Kao JY, Chen SY, Tsai MH, Huang SH, Lin $\mathrm{CW}$ : Proteomic identification of salivary transferrin as a biomarker for early detection of oral cancer. Anal Chim Acta 2010, 681(1-2):41-8.

46. Franzmann EJ, Reategui EP, Pedroso F, Pernas FG, Karakullukcu BM, Carraway KL, Hamilton K, Singal R, Goodwin WJ: Soluble CD44 is a potential marker for the early detection of head and neck cancer. Cancer Epidemiol Biomarkers Prev 2007, 16(7):1348-55.

47. Sugimoto M, Wong DT, Hirayama A, Soga T, Tomita M: Capillary electrophoresis mass spectrometry-based saliva metabolomics identified oral, breast and pancreatic cancer-specific profiles. Metabolomics 2010, 6(1):78-95.

48. Wei J, Xie G, Zhou Z, Shi P, Qiu Y, Zheng X, Chen T, Su M, Zhao A, Jia W: Salivary metabolite signatures of oral cancer and leukoplakia. Int J Cancer 2011, 129(9):2207-17.

49. Shpitzer T, Hamzany Y, Bahar G, Feinmesser R, Savulescu D, Borovoi I, Gavish M, Nagler RM: Salivary analysis of oral cancer biomarkers. Br J Cancer 2009, 101(7):1194-8

50. Zhong L, Chen G, Xu Z, Zhang X, Ping F, Zhao S: Detection of telomerase activity in saliva from oral squamous cell carcinoma patients. Int J Oral and Maxillofac Surg 2005, 34:366-370.

51. El-Naggar AK, Mao L, Staerkel G, Coombes MM, Tucker SL, Luna MA, Clayman GL, Lippman S, Goepfert H: Genetic heterogeneity in saliva from patients with oral squamous carcinomas: implications in molecular diagnosis and screening. J Mol Diagn 2001, 3(4):164-70.

52. Agha-Hosseini F, Mirzaii-Dizgah I, Farmanbar N, Abdollahi M: Oxidative stress status and DNA damage in saliva of human subjects with oral lichen planus and oral squamous cell carcinoma. J Oral Pathol Med 2012, 41(10):736-40

53. Bernabe DG, Tamae AC, Miyahara Gl, Sundefeld ML, Oliveira SP, Biasoli ER: Increased plasma and salivary cortisol levels in patients with oral cancer and their association with clinical stage. J Clin Pathol 2012, 65(10):934-9.

54. He H, Chen G, Zhou L, Liu Y: A joint detection of CEA and CA-50 levels in saliva and serum of patients with tumors in oral region and salivary gland. J Cancer Res Clin Oncol 2009, 135(10):1315-21.

55. Shpitzer T, Bahar G, Feinmesser R, Nagler RM: A comprehensive salivary analysis for oral cancer diagnosis. J Cancer Res Clin Oncol 2007, 133(9):613-7.

56. Tang H, Wu Z, Zhang J, Su B: Salivary IncRNA as a potential marker for oral squamous cell carcinoma diagnosis. Mol Med Rep 2013, 7(3):761-6.

57. Balan JJ, Rao RS, Premalatha BR, Patil S: Analysis of tumor marker CA 125 in saliva of normal and oral squamous cell carcinoma patients: a comparative study. J Contemp Dent Pract 2012, 13(5):671-5.

58. Shetty SR, Chadha R, Babu S, Kumari S, Bhat S, Achalli S: Salivary lactate dehydrogenase levels in oral leukoplakia and oral squamous cell carcinoma: a biochemical and clinicopathological study. J Cancer Res Ther 2012, 8(Suppl 1):S123-5.

59. Jessie K, Jayapalan JJ, Ong KC, Abdul Rahim ZH, Zain RM, Wong KT, Hashim OH: Aberrant proteins in the saliva of patients with oral squamous cell carcinoma. Electrophoresis 2013, 34(17):2495-502. 
60. Jou YJ, Lin CD, Lai CH, Tang CH, Huang SH, Tsai MH, Chen SY, Kao JY, Lin CW: Salivary zinc finger protein 510 peptide as a novel biomarker for detection of oral squamous cell carcinoma in early stages. Clin Chim Acta 2011, 412(15-16):1357-65.

61. Carvalho AL, Henrique R, Jeronimo C, Nayak CS, Reddy AN, Hoque MO, Chang S, Brait M, Jiang WW, Kim MM, Claybourne Q, Goldenberg D, Khan Z, Khan T, Westra WH, Sidransky D, Koch W, Califano JA: Detection of promoter hypermethylation in salivary rinses as a biomarker for head and neck squamous cell carcinoma surveillance. Clin Cancer Res 2011, 17(14):4782-9.

62. Contucci AM, Inzitari R, Agostino S, Vitali A, Fiorita A, Cabras T, Scarano E, Messana I: Statherin levels in saliva of patients with precancerous and cancerous lesions of the oral cavity: a preliminary report. Oral Dis 2005, $11(2): 95-9$.

63. Hoffmann RR, Yurgel LS, Campos MM: Evaluation of salivary endothelin-1 levels in oral squamous cell carcinoma and oral leukoplakia. Regul Pept 2011, 166(1-3):55-8.

64. Magnusson M, Pyykko I, van Setten G, Norlander T, Nastri A, Westermark A: Basic fibroblast growth factor (bFGF) in saliva and oral mucosa in patients with oral lichen planus: preliminary observations. Oral Surg Oral Med Oral Pathol Oral Radiol Endod 2004, 98(3):324-6.

65. Scully C, Beyli M, Ferreiro MC, Ficarra G, Gill Y, Griffiths M, Holmstrup P, Mutlu S, Porter S, Wray D: Update on oral lichen planus: etiopathogenesis and management. Crit Rev Oral Biol Med 1998, 9(1):86-122.

66. Neville BW, Day TA: Oral cancer and precancerous lesions. CA Cancer J Clin 2002, 52(4):195-215.

67. Rhodus NL, Cheng B, Myers S, Bowles W, Ho V, Ondrey F: A comparison of the pro-inflammatory, NF-kappaB-dependent cytokines: TNF-alpha, IL-1alpha, IL-6, and IL-8 in different oral fluids from oral lichen planus patients. Clin Immunol 2005, 114(3):278-83.

68. Teles RP, Likhari V, Socransky SS, Haffajee AD: Salivary cytokine levels in subjects with chronic periodontitis and in periodontally healthy individuals: a cross-sectional study. J Periodontal Res 2009, 44(3):411-7.

69. Zhang $Y$, Lin M, Zhang S, Wang Z, Jiang L, Shen J, Bai J, Gao F, Zhou M, Chen Q: NF-kappaB-dependent cytokines in saliva and serum from patients with oral lichen planus: a study in an ethnic Chinese population. Cytokine 2008, 41(2):144-9.

70. Arellano-Garcia ME, Hu S, Wang J, Henson B, Zhou H, Chia D, Wong DT: Multiplexed immunobead-based assay for detection of oral cancer protein biomarkers in saliva. Oral Dis 2008, 14(8):705-12.

71. Sharma M, Bairy I, Pai K, Satyamoorthy K, Prasad S, Berkovitz B, Radhakrishnan R: Salivary IL-6 levels in oral leukoplakia with dysplasia and its clinical relevance to tobacco habits and periodontitis. Clin Oral Investig 2011, 15(5):705-14.

72. Ebersole JL, Schuster JL, Stevens J, Dawson D 3rd, Kryscio RJ, Lin Y, Thomas MV, Miller CS: Patterns of salivary analytes provide diagnostic capacity for distinguishing chronic adult periodontitis from health. J Clin Immunol 2013, 33(1):271-9.

73. Thomas MV, Branscum A, Miller CS, Ebersole J, Al-Sabbagh M, Schuster JL: Within-subject variability in repeated measures of salivary analytes in healthy adults. J Periodontol 2009, 80(7):1146-53.

74. Kim JK, Zhou H, Nabili V, Wang MB, Abemayor E, Wong DT: Utility of multiple sampling in reducing variation of salivary interleukin-8 and interleukin-1 beta mRNA levels in healthy adults. Head Neck 2012, 35(7):968-73.

75. Jehmlich N, Dinh KH, Gesell-Salazar M, Hammer E, Steil L, Dhople VM, Schurmann C, Holtfreter B, Kocher T, Volker U: Quantitative analysis of the intraand inter-subject variability of the whole salivary proteome. J Periodontal Res 2012, 48(3):392-403.

76. Fraser CG: Inherent biological variation and reference values. Clin Chem Lab Med 2004, 42(7):758-64.

77. Denver R, Tzanidis A, Martin P, Krum H: Salivary endothelin concentrations in the assessment of chronic heart failure. Lancet 2000, 355(9202):468-9.

78. Lam HC, Lo GH, Lee JK, Lu CC, Chu CH, Sun CC, Chuang MJ, Wang MC: Salivary immunoreactive endothelin in patients with upper gastrointestinal diseases. J CardiovasC Pharmacol 2004, 44(Suppl 1):S413-7.

79. Dodds MW, Johnson DA, Yeh CK: Health benefits of saliva: a review. J Dent 2005, 33(3):223-33.

80. Denny PC, Denny PA, Klauser DK, Hong SH, Navazesh M, Tabak LA: Agerelated changes in mucins from human whole saliva. J Dent Res 1991, 70(10):1320-7.
81. Mankan AK, Lawless MW, Gray SG, Kelleher D, McManus R: NF-kappaB regulation: the nuclear response. J Cell Mol Med 2009, 13(4):631-43.

82. Hom D: Growth factors in wound healing. Otolaryngol Clin North Am 1995, 28(5):933-53.

83. Canakci C, Cicek Y, Yildirim A, Sezer U, Canakci V: Increased levels of 8-hydroxydeoxyguanosine and malondialdehyde and its relationship with antioxidant enzymes in saliva of periodontitis patients. European Journal of Dentistry 2009, 3:100-106.

84. Gursoy UK, Kononen E, Uitto VJ, Pussinen PJ, Hyvarinen K, Suominen-Taipale L, Knuuttila M: Salivary interleukin-1beta concentration and the presence of multiple pathogens in periodontitis. J Clin Periodontol 2009, 36(11):922-7.

85. Zhang L, Xiao H, Karlan S, Zhou H, Gross J, Elashoff D, Akin D, Yan X, Chia D, Karlan B, Wong DT: Discovery and preclinical validation of salivary transcriptomic and proteomic biomarkers for the non-invasive detection of breast cancer. PLoS One 2010, 5(12):e15573.

86. Xiao H, Zhang L, Zhou H, Lee JM, Garon EB, Wong DT: Proteomic analysis of human saliva from lung cancer patients using two-dimensional difference gel electrophoresis and mass spectrometry. Mol Cell Proteomics 2012, 11(2):M111 012112.

87. Bigler LR, Streckfus CF, Dubinsky WP: Salivary biomarkers for the detection of malignant tumors that are remote from the oral cavity. Clin Lab Med 2009, 29(1):71-85.

88. Streckfus C, Bigler L, Tucci M, Thigpen JT: A preliminary study of CA15-3, CerbB-2, epidermal growth factor receptor, cathepsin-D, and p53 in saliva among women with breast carcinoma. Cancer Invest 2000, 18(2):101-9.

89. Streckfus C, Bigler L, Dellinger T, Dai X, Kingman A, Thigpen JT: The presence of soluble c-erbB-2 in saliva and serum among women with breast carcinoma: a preliminary study. Clin Cancer Res 2000, 6(6):2363-70.

90. Zhang L, Xiao H, Zhou H, Santiago S, Lee JM, Garon EB, Yang J, Brinkmann O, Yan X, Akin D, Chia D, Elashoff D, Park NH, Wong DT: Development of transcriptomic biomarker signature in human saliva to detect lung cancer. Cell Mol Life Sci 2012, 69(19):3341-50.

91. Agha-Hosseini F, Mirzaii-Dizgah I, Rahimi A, Seilanian-Toosi M: Correlation of serum and salivary CA125 levels in patients with breast cancer. $J$ Contemp Dent Pract 2009, 10(6):E001-8.

92. Agha-Hosseini F, Mirzaii-Dizgah I, Rahimi A: Correlation of serum and salivary CA15-3 levels in patients with breast cancer. Med Oral Patol Oral Cir Bucal 2009, 14(10):e521-4.

doi:10.1186/2001-1326-3-3

Cite this article as: Cheng et al:: A review of research on salivary biomarkers for oral cancer detection. Clinical and Translational Medicine 2014 3:3.

\section{Submit your manuscript to a SpringerOpen ${ }^{\odot}$ journal and benefit from:}

- Convenient online submission

- Rigorous peer review

- Immediate publication on acceptance

- Open access: articles freely available online

- High visibility within the field

- Retaining the copyright to your article

Submit your next manuscript at $>$ springeropen.com 